\title{
Climate-Smart Agriculture (CSA): A review and analysis of policies, practices and local indicators in Nepalese context
}

\author{
Shree Kumar Maharjan \\ Graduate School of International Development and Cooperation, Hiroshima University, 1-5-1 \\ Kagamiyama, Higashi-Hiroshima City, Hiroshima, 739-8529, Japan \\ TEL: +81-82-424-6905 \\ Email: smilingsiri@gmail.com
}

\begin{abstract}
Climate-smart agriculture (CSA) is a new and emerging concept in climate discourse to address the issues of climate change impacts in agriculture. Few researchers and organizations have concentrated on CSA policies and practices in Nepal. This study aims to review and analyze the policies and practices in relation to CSA and define local level CSA indicators in the Central and Western Nepal. This study adopted the scoping review of climate policies and practices in Nepal and also utilized the household survey information particularly focusing on climate adaptation relating to agriculture. Through the scoping review, it is recognized that the number of climate policies in Nepal have specifically prioritized agriculture and food security as an important thematic area. Among those policies, National Adaptation Programme of Action (NAPA), National Framework for Local Adaptation Plan of Action (LAPA) and National Adaptation Plan (NAP) have specific sections on CSA practices, however these policies/plans lack specific indicators. Different categories of CSA practices are common in Nepal, but many of these practices are popular as agricultural and environmental practices prior to CSA concept and approach. The output indicators specific to CSA practices help the communities and policy makers to measure and monitor the progress of its implementation. Additional researches are required in this field to better understand the CSA concept, approaches and mechanisms in Nepalese context.
\end{abstract}

Keywords: Climate-smart, agriculture, adaptation, policies and practices, indicators

\section{Background}

Climate variabilities and impacts are increasing over the years. Increased temperatures, erratic rainfall patterns and increased intensity and frequency of extreme events such as floods, droughts, hot and cold waves, hailstorms are the indicators of changing climate and increment its impacts (FAO, 2013). Agriculture is one of the severely affected sectors among others due to climate impacts, which is witnessed from loss of agricultural lands, reduced agricultural production and productivity, increased and emergence of diseases and pests, loss of traditional landraces, drying of water sources among others. Once agriculture is impacted the whole livelihood and food security became affected, which ultimately disturbed the wellbeing and living standards and leads to continuation of vicious cycle of poverty. The vicious cycle can be changed through climate resilient or climate-smart agricultural policies and practices. Climatesmart agriculture (CSA) is an approach that transforms agriculture under changing climate through positively influencing livelihood, biodiversity and food security (Makote, 2019).

The concept of CSA first defined by FAO at Hague Conference on Agriculture in 2010 mainly to address the issue of climate impacts in agriculture by improving productivity, adapting and building resilience and reducing greenhouse gases (FAO, 2013; Khatri-Chetri, 2019). Multiple stakeholders including the government counterpart and civil society groups improvised, reformed and redesigned the concept based on their own contexts. In Nepalese context, CSA emphasized on increased in income, input use efficiency and gender/social inclusion in 
addition to productivity, adaptation and mitigation (Khatri-Chhetri, 2017). It has become central attraction in climate change and agricultural discourse recently (Khatri-Chettri, 2019). The agenda of sustainable development goals (SDGs) have also emphasized on food and nutrition security, zero hunger and economic growth and climate action. The most importantly, the agricultural production needs to be increased by 60 percent to feed the increasing population of 9 billion by 2050 (FAO, 2013).

CSA ranges from small change in crop management practice to whole transformation in agricultural practices with advanced technologies (Khatri-Chhetri, 2017). There are some controversies on CSA particularly in relation to its role and contribution to mitigation and sustainable agriculture and also consideration of biotechnology as CSA approach. However, this study mainly focuses on review of concept and recent developments of CSA policies and practices in Nepalese context. Furthermore, it aims to review and analyze the output indicators of CSA practices at the local level mainly in the Central and Western Nepal. Since it is new concept in Nepalese context, it is crucial to understand the concept and analyze the existing policies and practices from CSA perspectives. This study further contributes in the defining the local level output indicators in climate adaptation and CSA practices, which hasn't been studied in Nepalese context.

\section{Methodology}

The study adopted the scoping review of the existing literatures (published and unpublished papers) focusing on CSA in general and also CSA in Nepalese context in particular. The review specifically focused on climate policies/plans and practices to analyze the CSA perspectives in those policies and practices. Additionally, the data on climate adaptation and CSA practices extracted from household survey was used for analysis which was conducted in the Madi and Deukhuri valleys of the Central and Western Nepal respectively. The household survey was focused on climate impacts and factors affecting climate change adaptation in these valleys, which has specific section on adaptation and adoption CSA practices at the household level. The households were selected through systematic random sampling technique (154 and 150 in Madi and Deukhuri valleys respectively). Most of the households rely on agriculture for their livelihood and food security in both valleys, which is affected mainly from floods, droughts, riverbank erosions. The household data particularly on CSA section were analyzed for this study to define the local CSA indicators in the selected valleys.

The Madi valley is located in the southern part of Chitwan district in the Central Nepal. It is newly declared municipality with the total area of $238.55 \mathrm{Km} 2$ located in the South of the district. As per the district profile and municipal planning, Madi valley is prone to wildlife attacks, forest exploitations, flood and flood induced riverbank erosion (Madi Municipality, 2073/74 V. S1.). The district has the altitude ranges from 141 to 1947 meter above sea level with tropical to subtropical climate. The Deukhuri valley is located in the south of Dang district in Mid-western Nepal, borders to India in the south. The total area coverage by the district is $2,955 \mathrm{Km} 2$ with the altitude ranges of 213 to 2058 meter above sea level and the climatic variation tropical, subtropical and temperate. The government has implemented local adaptation plan of actions in 7 village development committees (VDCs) of the district under the Nepal Climate Change Support Programme (NCCSP). Based on the overall vulnerability index (VI), Chitwan is ranked as highly vulnerable and Dang as low vulnerable. However, the vulnerabilities, risks, impacts and adaptation interventions vary even within the district due to the variations in altitude and climate. The Deukhuri valley faces the issues of flood, riverbank erosion, drought, forest exploitation, reduced agricultural production and emergence of new

\footnotetext{
${ }^{1}$ V. S. is Vikram Sambhat, Nepalese Calendar which is 57 years earlier than A.D.
} 
insects, diseases and pests, drying of the water sources (Gangaparaspur VDC, 2070 V. S.; Sisahaniya VDC, 2073 V.S.).

\section{Results and discussion}

\subsection{CSA policies}

Appropriate policies and enabling environment are crucial for effective implementation and adoption of CSA practices and technologies (CCAFS, 2019). CSA is somehow reflected in climate change policies, plans and strategies such as National Adaptation Programme of Action (NAPA), National Adaptation Plans (NAPs), National Appropriate Mitigation Action (NAMA) at the national level and Local Adaptation Plan of Action (LAPA) at the local level (Table 1). Agricultural development plans and policies have also integrated CSA practices and approaches. However, there is a misconception among wider public that it's mainly the government's responsibility to implement these policies. It's not only government sole responsibility to execute these policies. The stakeholders have to contribute their expertise and specific roles for its successful implementation. In Nepalese context, the stakeholders had effectively participated and contributed in the formulation of these policies at the national and local level (Kaur, 2014). NAPA, itself, has developed a multi-stakeholder framework of action on climate change (MoE, 2010). However, same level of participation and contribution was not observed in terms of effective implementation of these policies. Even the meeting of Multistakeholder Climate Change Initiatives Coordination Committee (MCCICC) was not convened on regular basis.

Table 1: Climate change and agricultural related policies in Nepal

\section{Domain}

Agri. and food security

(actity

Climate

change

\begin{tabular}{|l|l} 
& \\
\hline Climate
\end{tabular}

Policies

\section{Institutions}

Agriculture Development Strategy (2014), Agriculture Development Policy (2004), Agriculture Extension Strategy (2014), National Biodiversity Strategy (2014), Agrobiodiversity Policy (2014)

Intended Nationally Determined
Contribution to UNFCCC (2014), Climate Change and Risk Management Framework (20112022), Climate Change Policy, NAPA, LAPA, Low Carbon Economic Development Strategy (2015)

Source: Khari-Chhetri, (2017)

NAPA is the first climate related policy/plan in Nepal developed in 2010, which has included the list of prominent proposals and planned activities related to agriculture in its combined profiles and annex 8. It has integration of adaptation strategies and low carbon emission development. However, it assumed to sufficiently raise the financial resources for implementation (MoE, 2010). The national LAPA framework development process followed the participatory action research and active involvement of stakeholders at the national and local level. Agriculture and food security are one of the themes under LAPA framework as well. The pilot (10 sites) and implementation phases (69 village development committees and 
one municipality in 14 districts) of LAPA framework integrated specific CSA practices and lessons (Kaur, 2014). It is also important to reflect CSA in the organizational policies of related stakeholders as well.

Climate change policy is an overarching policy relating to climate change in Nepal. It also emphasizes on adaptation and mitigation through building resilience of local communities, low-carbon economic development and implementation of adaptation related programmes to maximize the benefits (MoFE, 2018). However, it doesn't have specific focus on climate-smart agriculture since it is a national policy guiding document. However, it has underlined the requirement of research and assessment of detail climate impacts and necessary addressing mechanisms in agriculture and other affected sectors. Nepal's National Adaptation Plan (NAP) has focused on integration of adaptation into new and current policies, programmes and activities. It has also prioritized agriculture and food security as the important thematic area with adaptation pathways, which included development of adaptation technologies, resilient varieties, breeds, efficient irrigation and water efficient systems, climate resilient agriculture insurance and climate information system etc. (MoFE, 2018).

Agricultural development strategy has small section climate change, natural disaster and global crises management, but not specifically on climate-smart agriculture. However, it has provided some examples of crop and livestock insurance to address the consequences of climate variability (ADB, 2013; MoAD, 2014). Likewise, National agricultural policy (2004) has specifically stated about the appropriate agricultural technologies including irrigation, agricultural roads and rural electrification utilizing the comparatively advantages and special opportunities. But it has not revealed anything related to climate change adaptation and climate-smart technologies. it has given emphasized on increasing productivity, utilizing appropriate technologies including livestock insurance, organic farming and high yielding improved seeds and breeds, local original agricultural products and technologies and also participatory research and development (Nepal Law Commission, 2004). Since agriculture has significant contribution in national GDP and it is one of most affected sectors from climate change in Nepalese context, the climate-smart practices and technologies should be top priorities in the agricultural policies and strategies. The separate climate-smart agriculture policy would be applicable since it focuses on increasing productivity, adaptation, mitigation, increasing income and input use efficiency and gender/social inclusion. The climate-smart agricultural technologies, practices and services need to be identified based on the agroecological zones of Nepal based on the assessments of climatic risks across the country (KhatriChhetri, 2017). He further emphasized on 'tested evaluation portfolio of CSA potions at the farmer's fields and extrapolation of CSA assessment results at the country level' (KhatriChhetri, 2017 pp 10).

\subsection{CSA entry points and practices}

The farmers in both study valleys have faced different climate impacts, thus, they have practiced CSA by themselves and with the support of local stakeholders. With these CSA practices, the farm productivity has increased in most of the cases and the farmer's adaptive capacity and skills also enhanced through training and exposure to different CSA practices and technologies. However, the reduction of greenhouse gases, which is another pillar of CSA approach, need to be somehow managed that can be possible with the integration of forest and agro-forestry since Nepalese agriculture has integrative association with forestry and biodiversity. Makate (2019) also found number of CSA practices that have improved the farm productivity income and food security. Thus, if these practices are adopted in large scale, the climate change impacts would be minimized significantly. But there is comparatively less 
adoption of these CSA practices or technologies in low-income and developing regions (Campbell et al. 2014). Affordability and accessibility of the farmers for adopting new practices or technologies, lack or limited risk-bearing capacities and technical knowhow due to socio-economic conditions are some of the reasons for less adoption of these practices and technologies. Lack of evidence or success stories of these practices is one of reason of low adoption rate in these regions/countries (Aggrawal et al. 2018).

The research and assessment of needs and existing situation of the farmers in addition to climate vulnerabilities and impacts might enhance the adoption rate of CSA. Furthermore, Khatri-Chhetri (2017) emphasized on financial supports, incentive mechanisms and proper information dissemination strategies through extension services for upscaling of CSA practices and technologies in addition to policy and institutional support. It is observed that some of the existing agricultural and environmental practices and technologies are re-defined as CSA practices. The CGIAR Research Program on Climate Change, Agriculture and Food Security (CCAFS) has defined 3 entry points - CSA practices, CSA systems approaches and CSA enabling environments. It has further categorized CSA practices into 7 groups, namely soil management, crop management, water management, livestock management, forestry, fisheries and aquaculture and energy management. However, in Nepalese context, forestry and energy management are not included directly under agricultural practices, though these interventions complemented agriculture is some or other ways. This study followed the same categories of CSA interventions guided by the CCAFS (Table 2).

Table 2: Examples of CSA practices and interventions in Nepal

\begin{tabular}{|c|c|c|}
\hline $\begin{array}{c}\text { CSA } \\
\text { Mechanisms }\end{array}$ & Examples of CSA Practices & Specific CSA cases \\
\hline $\begin{array}{l}\text { Soil } \\
\text { Management }\end{array}$ & $\begin{array}{l}\text { sustainable land management, zero } \\
\text { tillage, mixed farming, agro-foresty, } \\
\text { slopping agriculture land technology }\end{array}$ & $\begin{array}{lrr}\text { Slopping } & \text { agriculture } & \text { land } \\
\text { technology } & \text { (SALT), mixed } \\
\text { farming, permaculture } & \\
\end{array}$ \\
\hline $\begin{array}{l}\text { Crop } \\
\text { Management }\end{array}$ & $\begin{array}{l}\text { High yielding and resilient } \\
\text { crops/varieties, crop diversification, } \\
\text { seedbanks, integrated pest } \\
\text { management, alternative crop farming, } \\
\text { crop insurance }\end{array}$ & $\begin{array}{l}\text { switching crop species (maize } \\
\text { replacing rice), insect/disease } \\
\text { resistant and early maturing rice, } \\
\text { flood tolerant rice varieties, } \\
\text { riverbed farming }\end{array}$ \\
\hline $\begin{array}{l}\text { Water } \\
\text { Management }\end{array}$ & $\begin{array}{l}\text { Rain water harvesting, low-cost gravity } \\
\text { flow drip irrigation, fertigation, } \\
\text { sprinkler, aquaponics, water } \\
\text { conservation tank/pond, System of rice } \\
\text { Intensification (SRI), drought resistant } \\
\text { varieties }\end{array}$ & $\begin{array}{l}\text { alternative wetting and drying } \\
\text { rice farming, low cost drip } \\
\text { irrigation, kitchen waste-water } \\
\text { management, aquaponics in } \\
\text { Nepal }\end{array}$ \\
\hline $\begin{array}{l}\text { Livestock } \\
\text { Management }\end{array}$ & $\begin{array}{l}\text { Trans-humane livestock management, } \\
\text { resistant breeds, livestock insurance, } \\
\text { mixed crop livestock systems, } \\
\text { permaculture, early warning system, } \\
\text { supplementary feeding of Leucaena to } \\
\text { cattle }\end{array}$ & $\begin{array}{l}\text { Trans-humane livestock } \\
\text { movement, livestock insurance, } \\
\text { early warning system, }\end{array}$ \\
\hline Forestry & $\begin{array}{l}\text { Ecosystem services, carbon } \\
\text { sequestration \& sink, afforestation, } \\
\text { farms and forests, sustainable forest } \\
\text { management, community forestry, } \\
\text { agro-forestry }\end{array}$ & $\begin{array}{l}\text { Community forestry, leasehold } \\
\text { forestry and REDD+ in Nepal, } \\
\text { leasehold forestry }\end{array}$ \\
\hline
\end{tabular}




\begin{tabular}{|l|l|ll|}
\hline $\begin{array}{l}\text { Fisheries and } \\
\text { Aquaculture }\end{array}$ & $\begin{array}{l}\text { Ecosystem approach for fishing and } \\
\text { aquaculture, poultry mixed with } \\
\text { aquaculture, selective breeding, } \\
\text { aquaponics and hydroponics }\end{array}$ & $\begin{array}{l}\text { Aquaponics, pig/poultry cum } \\
\text { fish farming }\end{array}$ \\
\hline $\begin{array}{l}\text { Energy } \\
\text { Management }\end{array}$ & $\begin{array}{l}\text { Renewable energy sources - } \\
\text { bioenergy, solar energy, micro-hydro, } \\
\text { biogas, biodiesel, bio-briquettes, liquid } \\
\text { biofuels }\end{array}$ & Biogas, micro-hydro \\
\end{tabular}

\subsection{CSA Indicators}

Indicators are important for effective monitoring and evaluation of the progresses in climate discourse. However, very few of adaptation interventions in Nepal have adopted the CSA indicators. In this study, the output indicators were categorized following the CCAFS in the central and western Nepal based on the household survey, which is presented in Table 3 . These indicators help in measuring the dimensions of CSA that ultimately provide guidance and framework to the policy makers and practitioners to implement and monitor and evaluate the successes (WB, 2016). One of the reasons for less adoption of CSA practices was lack of evidences and success stories. In that sense, the CSA indicators would help in documenting the success cases and also in the process of monitoring and evaluation. These indicators also assist in identifying and prioritizing the locally appropriate and context specific CSA technologies and practices (Mwongera et al., 2017). In this process, the participatory approaches and tools including the bottom up, qualitative and quantitative methods could be utilized for the assessment of CSA practices (Mwongera et al. 2017).

The CSA indicators capture the direct outputs and behavioral changes of the stakeholders including producers, policy makers and civil society (WB, 2016). There are different types of CSA indicators defined by different agencies. For instance. The CCAFS has defined three levels of CSA indicators - readiness phase indicators, process indicators, outcome/output indicators, depending on the time of monitoring and measuring the progresses. Whereas, WB (2016) has defined 3 CSA indices - CSA policy index, CSA technology index and CSA Result Index and specific CSA indicators based on these indices. Quinney et al. (2016) formulated specific CSA indicators for productivity emphasizing on yields, yield gaps, sale of agricultural produces, income and livelihood security. Likewise, they have defined specific indicators for adaptation mainly focusing on risk management, adaptation practices and technologies and enabling environment. But only few indicators have been defined relating to varieties, crop insurance including the perception indicators. It is important to develop the indicators in line with the 3 pillars (productivity, adaptation and mitigation) of CSA. But only few indicators related to mitigation are available particularly focusing on mitigation issues and outcomes. More specific and varied indicators are required to adequately measure CSA outputs or outcomes in order to avoid the ambiguity and balance among these pillars of CSA.

Table 3: CSA indicators in Central and Western Nepal

\begin{tabular}{|c|l|l|}
\hline $\begin{array}{c}\text { CSA } \\
\text { mechanisms }\end{array}$ & \multicolumn{1}{|c|}{ CSA Practices } & \multicolumn{1}{c|}{ Output Indicators } \\
\hline $\begin{array}{c}\text { Soil } \\
\text { Management }\end{array}$ & - Construction of check & - Number of check dams constructed last \\
& dams & year \\
& - Bio-fencing & - Number of farmers adopted bio-fencing \\
& - Mixed farming & $\begin{array}{l}\text { - Percentage of cultivable land with fixed } \\
\text { farming }\end{array}$ \\
\hline
\end{tabular}




\begin{tabular}{|c|c|c|}
\hline $\begin{array}{c}\text { Water } \\
\text { Management }\end{array}$ & $\begin{array}{l}\text { - Construction of water } \\
\text { conservation ponds } \\
\text { - Traditional and improved } \\
\text { irrigation canals }\end{array}$ & $\begin{array}{l}\text { - Number of water ponds constructed } \\
\text { - Percentage of land irrigated from } \\
\text { ponds/canals } \\
-\quad \text { Number of irrigation canals } \\
\text { constructed/improved }\end{array}$ \\
\hline $\begin{array}{l}\text { Soil \& Crop } \\
\text { Management }\end{array}$ & $\begin{array}{l}\text { - Riverbed farming } \\
\text { - Check dams } \\
\text { - Plantations }\end{array}$ & $\begin{array}{l}\text { - Number of farmers adopting CSA } \\
\text { approaches including riverbed farming } \\
\text { - Percentage of destroyed land recovered } \\
\text { through riverbed farming } \\
\text { - Amount of income increased per } \\
\text { household } \\
\text { - Number of check dams constructed } \\
\text { - Number of bamboo plantations in the } \\
\text { riverbeds } \\
\text { - Percentage of affected land restored }\end{array}$ \\
\hline $\begin{array}{c}\text { Crop } \\
\text { Management }\end{array}$ & $\begin{array}{l}\text { - Change of cropping } \\
\text { patterns (less labor-intensive } \\
\text { farming) } \\
\text { - Mixed farming } \\
\text { - Use of local liquid } \\
\text { fertilizers }\end{array}$ & $\begin{array}{l}\text { - Number of farmers change from cereals } \\
\text { to fruit farming } \\
\text { - Number of farmers changed to fisheries } \\
\text { and poultry } \\
\text { - Number of farmers adopting mixed } \\
\text { farming } \\
\text { - Number of farmers integrated Dhaicha } \\
\text { (Sesbania sp.) and other insect repellant } \\
\text { species in the farms } \\
\text { - Number of farmers used the liquid } \\
\text { fertilizers }\end{array}$ \\
\hline $\begin{array}{c}\text { Financial } \\
\text { management }\end{array}$ & $\begin{array}{l}\text { - Increased financial } \\
\text { situation/capital for } \\
\text { agricultural diversification }\end{array}$ & $\begin{array}{l}\text { - Number of cooperatives and } \\
\text { microfinance in the locality } \\
\text { - Number of farmers accessing the local } \\
\text { credits/finances } \\
\text { - Number of ag. based enterprises initiated } \\
\text { by farmers }\end{array}$ \\
\hline $\begin{array}{c}\text { Livestock } \\
\text { Management }\end{array}$ & Livestock insurance & $\begin{array}{l}\text { - Number of farmers interested and joined } \\
\text { livestock insurance scheme }\end{array}$ \\
\hline $\begin{array}{ll} & \text { Human } \\
\text { skills } & \end{array}$ & $\begin{array}{l}\text { - Farm and non-farm related } \\
\text { training, capacity building } \\
\text { and exposure to the farmers }\end{array}$ & $\begin{array}{l}\text { - Number of trainings organized in the } \\
\text { locality } \\
\text { - Number of farmers participated in the } \\
\text { trainings, capacity building and exposures } \\
\text { - Percentage of participants applied new } \\
\text { skills, knowledge in the farming }\end{array}$ \\
\hline
\end{tabular}

\section{Conclusion and way forward}

Climate impacts have been aggravating particularly in agriculture sector. Agriculture, food security and climate-smart agricultural practices are someway reflected in climate change policies and plans in Nepal. But only few sections in the agricultural development strategy. In Nepalese context, being an agriculturally based country with more than $65 \%$ directly related to it and largely affected from climate change impacts every year, it is crucial to have specific sections on climate-smart technologies and climate-smart policies both at the national and local level. Since the country has recently transitioned to federal based government with added power and authority to the local government, this is appropriate time for the local government 
to develop and implement climate-smart agricultural technologies and practices based on the assessment of the local climatic contexts.

The farmers have tried to deal with the impacts by themselves and stakeholders including government, civil society groups have been also supporting farmers through different CSA policies and practices. CSA approach fulfill the triple wins (productivity, adaptation and mitigation) in agriculture. Multiple researches have been conducted in the world particularly in Asia and Africa focusing on CSA practices, but very few similar researches in Nepalese context. Thus, it is crucial to carry out researches and assessment on this discourse in Nepal. Some of the ongoing agricultural and environmental practices are also re-defined and included under the CSA practices. Some of agriculturalists have argued on such agricultural practices such as mixed farming, change in cropping patterns, resistant varieties etc. Additionally, there are controversies and debates on it which is still ongoing particularly in relation to roles in mitigation and biotechnology. Additional researches and discussions are required to sort out these arguments, issues and controversies. The CSA in Nepal needs policy supports, additional mechanisms, development and implementation of CSA practices.

\section{References}

ADB. 2013. Agricultural Development Strategy (ADS): Final report prepared for Government of Nepal with support of ADB, IFAD, EU, FAO, SDC, JICA, USAID, DANIDA, WFP, World Bank, Kathmandu, Nepal.

Aggarwal, P., R. Zougmore and J. Kinyangi. 2013. Climate-Smart Villages: A Community Approach to Sustainable Agricultural Development. The Consultative Group for International Agricultural Research's (CGIAR) Research Program on Climate Change, Agriculture, and Food Security (CCAFS), Copenhagen, Denmark.

Campbell, R. M., Thornton, P., Zougmore, R., van Asten, P., Lipper, P., 2014 Sustainable intensification: What is its role in climate-smart agriculture? Current Opinion on Environmental Sustainability. 8: 39-43. Doi: 10.1016/j.cosust.2014.07.002

CCAFS, 2019. Climate-smart agriculture 101. https://csa.guide/ (Accessed on 12 April 2019)

FAO, 2013. Climate-smart agriculture: Sourcebook. Food and Agriculture Organization of the United Nations. ISBN 978-92-5-107720-7 (print), E-ISBN 978-92-5-107721-4 (PDF)

Gangaparaspur VDC, 2070 V. S. Local adaptation plan of action (in Nepalese language). Gangaparaspur Village Development Committee, Dang

Kaur, N. 2014. Climate change planning in Nepal. Green Growth Best Practice (GGBP) Case Study Series. Global Green Growth Institute, European Climate Foundation, CDKN, Ministry of Foreign Affairs of the Netherlands \& UKaid http://www.greengrowthknowledge.org/sites/default/files/downloads/bestpractices/GGBP\%20Case\%20Study\%20Series_Nepal_Climate\%20Change\%20Planni ng.pdf (Accessed on 3 July 2019)

Khatri-Chhetri, A. 2017. Assessment of climate-smart agriculture (CSA) options in Nepal. CGIAR Research Program on Climate Change, Agriculture and Food Security (CCAFS), New Delhi, India

Khatri-Chhetri, A., Pant, A., Aggarwal, P. K., Vasireddy, V. V., Yadav, Al 2019. Stakeholders prioritization of climate-smart agriculture interventions: Evaluation of a framework. Agricultural systems. 164: 23-31. Doi: 10.1016/j.agsy.2019.03.002

Madi Municipality, 2073/74 V. S. Annual Municipal Development Plan (in Nepalese language). Madi Municipality, Government of Nepal, Chitwan

Makate, C. 2019. Effective scaling of climate-smart agriculture innovations in African smallholder agriculture: A review of approaches, policy and institutional strategy needs. Environmental Science and Policy. 96: 37-51. Doi: 10.1016/j.envsci.2019.01.014 
MoE, 2010. National adaptation programme of action (NAPA) to climate change. Ministry of Environment, Government of Nepal. Singha Durbar, Kathmandu, Nepal

MoFE, 2018. Nepal's national adaptation plan (NAP) process: Reflecting on lessons learned and the way forward. Ministry of Forests and Environment (MoFE), Government of Nepal, the NAP Global Network, Action on Climate Today (ACT) and Practical Action Nepal

Mwongera, C., Shikuku, K. M., Twyman, J., Laderach, P., Ampaire, E., Asten, P. V., Twonlow, S., Winowiecki, L. A. 2017. Climate-smart agriculture rapid appraisal (CSA-RA): A tool for prioritizing context-specific climate-smart agriculture technologies. 151:192203. Doi: 10.1016/j.agsy.2016.05.009

Nepal Law Commission, 2004. National Agricultural Policy, 2004. www.lawcommission.gov.np (Accessed on 5 July 2019)

Quinney M, Bonilla-Findji O, Jarvis A. 2016. CSA Programming and Indicator Tool: 3 Steps for increasing programming effectiveness and outcome tracking of CSA interventions. CCAFS Tool Beta version. Copenhagen, Denmark: CGIAR Research Program on Climate Change, Agriculture and Food Security (CCAFS). https://ccafs.cgiar.org/csaprogramming-and-indicator-tool\#.XPYNUdMzaME, accessed on May 29, 2019

Sisahaniya VDC, 2073 V. S. Village Profile. Sisahaniya Village Development Committee, Dang

WB, 2016. Agriculture global practice: Climate-smart agriculture indicator. The World Bank. World Bank Group Report Number 105162 GLB. 